\title{
IMPACT OF SAFETY HEALTH ENVIRONMENT ON EMPLOYEE RETENTION IN PHARMACEUTICAL INDUSTRY: MEDIATING ROLE OF JOB SATISFACTION AND MOTIVATION
}

\author{
Saad Salman 1 \\ Institute of Professional Development, University of Engineering and Technology, Lahore, \\ Pakistan \\ Asif Mahmood ${ }^{2}$ \\ Institute of Business \& Management (IB\&M), University of Engineering and Technology, \\ Lahore, Pakistan \\ Faisal Aftab ${ }^{3}$ \\ Department of Research, Bahria University, Islamabad, Pakistan \\ Atif Mahmood 4 \\ Lahore Business School, University of Lahore, Pakistan
}

\begin{abstract}
Purpose: This study analyzes how employee retention is influenced by factors like safety health environment, job satisfaction and motivation.

Methodology/Sampling: This research is quantitative in nature, where 250 survey questionnaires have been distributed within the employees of pharmaceutical industry in Pakistan. SPSS and AMOS have been utilized to analyze the direct and mediating effect of variables.

Findings: This study confirms that employee retention is a significant outcome of safety health environment. Moreover, the levels of job satisfaction and employee motivation equally mediate the relationship between safety health environment and employee retention. Practical implications: The findings of this paper suggest that the pharmaceutical firms in Pakistan and specifically in Lahore should foster the health protection policies, and in turn it would help enhance the satisfaction and motivation in staff, resulting in the retention of capable employees.
\end{abstract}

Key terms: Safety health environment, job satisfaction, motivation, employee retention, Pharmaceutical industry

* The material presented by the author does not necessarily portray the viewpoint of the editors and the management of the Institute of Business \& Technology (IBT)

\footnotetext{
1Saad Salman

2 Asif Mahmood

3 Faisal Aftab

:saaduet045@yahoo.com

:drasif@uet.edu.pk

:faftad@bahria.edu.pk

4 Atif Mahmood

:dratif71@gmail.com

(C) IBT-JBS is published by the Institute of Business and Technology (IBT).
}

Main Ibrahim Hydri Road, Korangi Creek, Karachi-75190, Pakistan. 


\section{INTRODUCTION}

Employee retention describes the procedures and resources used for encouraging the employees to remain associated with their firms (Akila, 2012). This phenomenon is imperative for both the organizations as well as its staff (Akila, 2012). In this global era, apart from competing with other firms in terms of innovativeness and technology, a number of organizations invest huge amounts of money to train their workforce in order to develop their skills or competencies (Arnold 2005). The organizations further desire such efficient employees to be retained (Bernsen et al. 2009). According to Alkandari (2009) such employee retention programs are highly effective and can retain or attract employees. Moreover, Klein et al. (1994) suggest that because retention can happen at numerous positions. However, many firms bear high cost of employee turnover (Nawaz, et al., 2012). One reason behind this prevailing problem is the retirement of skilled staff, where expenditure of hiring and training new employees is high (Hiltrop 1999). Secondly, employees intentionally exit because of dissatisfaction, de-motivation or other grievances at work (Coff, 1997).

This is why the concept of safety health environment has emerged as a solution to employee turnover and a key for employee retention. According to Miller, et al. (2001) employees obtain benefits from their working environment (safety and health environment). Moreover, these benefits derive the sense of belonging in employees and aid in enhancing their motivation level. Therefore, essence of retaining competent workers is to provide appropriate level of jobs and job environment (Sutherland, 2004). Furthermore, companies require focusing on ways to boost mental and physical health of their employees, which in turn will significantly lead to their retention (Lowe, 2003). Previous researchers on this topic highlight that increasing the safety standards and levels at work retained nursing staff (Aiken, 2011; Sermeus et al., 2011). Likewise, a study in medical colleges proved that health, safety and personal well-being of staff improves the motivation (Saeed and Ahmad, 2014). In the same way, safety and health concerns by firms can progress the job satisfaction and performance of employees (Mardiana et al. 2012).

Yet this relationship has not been given due consideration within the framework of pharmaceutical industry in Pakistan. Nevertheless, examining this notion is vital as, today, globalization has lead to the need of improving trade and the sectors facilitating in trade. In this regard, manufacturing sector is considered highly important for any country, and thus for Pakistan (Ara, I, 2004). Conclusively, this research has developed following objectives. First, this study extends previous researches and determines the effect of safety health environment on retention of employees working in Pharmaceutical industry of Pakistan. Secondly, the mediating role of job satisfaction between the relationship of safety health environment and employee retention is examined. Third, is explored whether motivation of employees plays any part in mediating the effect of safety health environment on employee retention. 


\section{LITERATURE REVIEW}

\subsection{Safety Health Environment and Employee Retention}

Safety and health needs lie among the five pyramids of Maslow's hierarchy of needs. This include health, personal security, and well-being (Maslow, 1943). In case of employee-employer relationship, a work environment provides suitable physical and mental conditions for employees. However, lack of these conditions cause issues such as anxiety or depression, which further deviates the employees from work (Boorman, 2009). Work environment is described as the physical surroundings e.g. noise, equipment, ventilation and temperature etc (Jain and Kaur, 2014). Employees are more probable to stay in the company where an expectable job atmosphere is maintained (Zuber, 2001), and with insufficient working situations like poor lighting, unsatisfactory furniture etc, employees are unwilling to perform for longer periods of time (Shamsuzzoh \& Suman, 2010).

Main focus of organizations has remained on offering better jobs to employees as well as to retain them by providing good work environment (Sutherland, 2004). For this purpose, firms generate and maintain a setting where employees feel comfortable to work and find growth opportunities (Winterton, 2011). This essential environment is created for the needs of current as well as future employees, and specifically organizations involve their high performing employees during downturns in economy (Ongori, 2008). Minimizing the occurrence of workplace violence and availability of health care facilities aid in employees' retention (Clements et al., 2003; Lowe et al., 2003). This forms the basis of first hypothesis of this paper, which is:

\section{H1: There is significant relationship between safety health environment and employee retention.}

\subsection{Safety Health Environment and Job Satisfaction}

Job satisfaction represents the perception and evaluation of employees regarding their jobs (Ivancevich et al. 1997; Paul, 2001; Akýncý, 2002). A pleasing work environment creates satisfaction (Spector, 1985), in turn the employees experiencing cheerful feelings at work give more consideration to job tasks (Davies, Sirett \& Taylor, 2001). The changes in safety and health concerns have a potential effect on various aspects of job satisfaction (Spurgeon, 2003). For current time as well as for long term (Amador, et al., 2008). Moreover, an improved internal control report regarding health and safety activities develops satisfaction in employees. However, this satisfaction is observed more for mental health as compared to physical safety (Gaupseth, 2000). Furthermore, researches of (Luddy, 2005; Makie and Smit, 2006; Mariani et al., 2003) point out that unsafe working conditions, over bearing workloads and other job related environmental fundamentals are liable for dissatisfaction of professionals, and this dissatisfaction can also prompt employees to search for better work opportunities. Yet, this ineffective management and safety/health procedures which roots poor working for employees, can be improved by considerable contributive factors (Akerstedt et al., 2002). Thus, our second hypothesis is: 


\section{H2: There is significant relationship between safety health environment and job satisfaction.}

\subsection{Safety Health Environment and Motivation}

Motivation is one of the most important success factors of any company (Johnson, 2000). It is defined in many different ways. Shief (2001) state that motivation is a drive or stimulus through which employees achieve the organizational goals. In this regard, Maslow's hierarchy of needs theory, which is regarded as the most accepted theory of motivation denotes that employees are motivated by their want to satisfy specific needs (Hansia, 2009). Motivation is derived from pleasure of work itself, from monetary achievement, promotion at job or by successfully completing tasks (Elnaga, 2013). Likewise, employees obtain benefits through working environment (safety and health environment), which give an appropriate level of sense of belongingness to employees. This association further results in having control on workspace, and due to such control employees can enhance their motivational level (Miller, et al., 2001). In the same way, it is reported that bad health deficiency is lesser in extremely aggravated, unavailable and well managed employees, who are working in premium jobs (Coats and Max, 2005). Therefore, third hypothesis is postulated as:

\section{H3: There is significant relationship between safety health environment and motivation.}

\subsection{Job Satisfaction and Employee Retention}

A number of studies have been carried out to prove the relationship of job satisfaction and retention (Firth et al., 2004). They specify the factors of dissatisfaction which create desire to quit from an organization. Samuel and Chipunza (2009) state that for mental satisfaction, employees give a great amount of importance to workplace and social factors such as consistency in economic conditions and salary. Further studies establish a powerful evidence of linking job satisfaction with retention of workers. Job satisfaction is considered an imperative factor for employee retention (Wetprasit, 2006), where employees with good performance when feel contended with their workplace, do not intend to switch jobs (Mc Shane \& Glinow, 2005). Positive perception with jobs retains employees and negative perception increases turnover rate (Light, 2004). Hence, fourth hypothesis is established as:

\section{H4: There is significant relationship between job satisfaction and employee retention.}

\subsection{Motivation and Employee Retention}

Bevan et al (2009) concludes that absence of sickness can also effect employee retention. The employees who are de-motivated from their work or stressful and poor working relationships with other colleagues are more probable to resign from their 
posts (Bevan et al., 2009). However, long term illness and chronic conditions of employees can be rehabilitated. Wilson, Brown \& Cregan (2008) further prove that at present, it has become important for organizations to restore work in order to create excellence in jobs, primarily to increase employee motivation. Similarly, Miner, et al. (1995) state that motivation is a psychological process, and the environment of competitive problems is mostly motivational. The attitude, perception, learning and motivational part of the behavior effects employee retention. Conclusively the fifth hypothesis is developed as:

\section{H5: There is significant relationship between motivation and employee retention.}

\section{RESEARCH METHODOLOGY}

Based upon the above discussed review of literature, a theoretical framework has been developed and presented in Figure 1. It is formed to examine the effect of safety health environment on employee retention and to determine the mediating role of job satisfaction as well as motivation in deriving this relationship.

\subsection{Sampling and Data collection}

Since 1947, Pharmaceutical industry in Pakistan has undergone immense development. According to the National Drug Policy of Pakistan, there are 338 national and 30 multinationalÊpharmaceutical firms currently operating in Pakistan, and out of the total 368 firms, 104 are functioning in Lahore. Therefore, based upon convenient sampling technique, we sampled the employees of Pharmaceutical companies of Lahore. Data was primarily collected by distributing a survey questionnaire to the work force employed in these companies. Before getting the final questionnaires filled, a pilot study was carried out on 30 employees. The result did not show any deviation, thus approving the questionnaire for whole sample. Total of 250 questionnaires were distributed and 213 were received back. However, because of missing data and incomplete information, only 200 questionnaires were used for analyzing the data. The informants were approached after taking permission from the concerned authorities of Pharmaceutical firms, they were assured of confidentiality of data and also they were invited to participate upon their own consent.

\subsection{Measures}

Survey instrument used in present study has been adopted from (Parasuraman, Zeithaml, \& Berry, 1988). It consisted of 24 questions. First three questions measured demographical characteristics of employees and the remaining measured variables; Safety Health Environment (SHE), Job Satisfaction (JS), Motivation (MOT), and Employee Retention (ER). All variables were operationalized on a five-point Likert scale (strongly agree $=5$ to strongly disagree $=1$ ). Further, safety health environment was determined through 7 items, job Satisfaction has been measured using 5 items, four questions were incorporated to measure the employees' level of motivation, and responses for employee retention were collected through 5 items respectively. 


\section{RESEARCH FINDINGS}

Before analyzing the data, all necessary tests for checking linearity, normality, heteroskedasticity, autocorrelation, detection of outliers and multicollinearity were applied. Results of all tests were proved satisfactory, therefore we proceeded further for reliability and regression analysis. The reliability statistics for all included variables was measured using Chronbach's alpha, and for all variables it was evidenced to be above 0.7, proving adequateness (Fornell \& Larcker, 1981). Furthermore, SPSS 18 and AMOS 18 have been utilized to perform correlation, regression and path analysis (Suliman, 2002).

\subsection{Descriptive Statistics and Correlation}

Descriptive statistics of data shows that the sampled population consists of 176 (88\%) male and 24 (12\%) female employees of pharmaceutical companies. Similarly, based upon the age, respondents have been classified in 4 groups including. $8(4 \%)$ are less than 25 years old, 49 (24.5\%) are between 25-35 years, 57 (28.5\%) are fall among $35-45$ years old, and 58 (29\%) are 45 plus. These results show that most of our informants belong to the age group above 45 years. With respect to qualification level, 12 (6\%) employees have degrees below matriculation, 50(25\%) employees have studied up to intermediate, $75(37 \%)$ are bachelor degree holders, $47(23 \%)$ are having masters degree, while remaining $16(8 \%)$ lie in the category of other education. On average the employees are graduates. Since, the data was normally distributed and linear relationship existed between variables, thus Pearson correlation was used to assess the link. Correlation coefficients indicate a significant positive relationship between all variables such as SHE and JS ( $r=0.497, \mathrm{p}<.01)$, SHE and MOT $(r=0.337<\mathrm{p}<0.01)$, SHE and ER $(r=0.526, p<0.01)$. Moreover, JS and ER also have same positive relationship $(\mathrm{r}=0.650, \mathrm{p}<.01)$, JS and MOT $(\mathrm{r}=0.418, \mathrm{p}<.01)$. In addition, MOT and ER are further significantly correlated $(\mathrm{r}=0.579, \mathrm{p}<0.01)$.

\subsection{Structural Equation Modeling (SEM)}

After we confirmed the relationship between all variables, structure equation modeling (SEM) had been utilized to check the theoretical model and to measure the dimensionality and validity of Safety Health Environment (SHE), Job Satisfaction (JS), Motivation (MOT), and Employee Retention (ER). The proposed framework is given in Figure 2. The model fit indices were computed as a result of SEM. Values indicate that all indices fall within the acceptable criteria (Hu \& Bentler, 1999), where standardized RMR and Root Mean Square are less than 0.1 (Browne and Cudeck, 1993; Kline, 2010). Values of GFI= 0.95, CFI= 0.92, NFI= 0.92, $\mathrm{EFI}=0.902$, IFI=0.93, RFI= $1.1, \mathrm{RMR}=0.94$ and alpha $=0.934$ are above the value 0.9 . Furthermore, RMSEA $=0.13$ is also in acceptable range as it is equal to 0.1 .

Values given in Table 1 illustrate that employee retention is significantly and positively influenced by safety health environment. That is when safety health environment increases by one unit, employee retention also rise up by 0.246 units. This result shows the proposed hypothesis $\mathrm{H} 1$ is accepted. Also, safety health environment is significantly 
and positively impacting job satisfaction, and when safety health environment increases by one unit, job satisfaction also rise up by 0.592 units. This result too shows that the proposed hypothesis $\mathrm{H}_{2}$ is accepted. Furthermore, the impact of safety health environment on motivation is significant and positive, that is when safety health environment increases by one unit, motivation also rise up by 0.261 units. This result again proves $\mathrm{H} 3$. Likewise, job satisfaction is significant and positively affecting employee retention, when job satisfaction increases, employee retention also rise up by 0.397 units. Hence, $\mathrm{H} 4$ is also proved. Similarly, motivation creates significant and positive impact on employee retention by 0.512 units, thus confirming $\mathrm{H}_{2}$. Finally, these results state that positive significant relationship between safety health environment and employee retention is direct, as well as indirect, through mediations of job satisfaction and motivation in pharmaceutical industry of Lahore Pakistan.

\section{CONCLUSION}

This study was intended to investigate the impact of safety health environment on employee's retention with the mediating role of motivation and job satisfaction within the manufacturing sector (pharmaceutical industry) of Pakistan. Globally, a lot of literature is present about employee retention. Yet within the context of Pakistan, a limited amount of research is available on this subject. Previous studies have explored the association between safety health environment and employee retention and also motivation as mediating variable, however, a gap is observed that motivation as well as job satisfaction as mediators in relationship between safety health environment and employee retention are not studied. The current research is significant as, in pharmaceutical industry, the health and safety $(\mathrm{H} \& \mathrm{~S})$ of employees is a vital issue, where health and safety policies are concerned with protecting the employees in organization's activities. (Toole, 2002). With increasing industrialization, consequent increase in industrial accidents and exposure to dangerous chemicals have health implications for employees (Waring, 1996; Lingard et al, 2010; Pollitt, 2011). Lowe (2003) studies that retaining the workers are important for their mental and physical health, this is why, and companies need to focus on workplace, which is suitable for workers according to their health. Provided the safety welfare by management, employees stay satisfied with their job and perform well (Logasakthi \& Rajagopal, 2013). In general, health and safety environment given by company tends to reduce employee turnover and on the other side increases retention.

\subsection{Direction for future research}

For future studies, the researchers suggest an enlargement of the sample size to give effect to a possible generalization of findings; this study can be extended to other countries, and comparative examination of the private and public sectors. My study consists on some specific variables but here may be many other variables which can affect this study, so others (researchers) should also study all other variables for further research in the future. And utilize research information to develop recommendations for an employee retention programs. 


\section{REFERENCES}

Akerstedt, T., Knutsson, A., Westerholm, P., Theorell, T., Alfredsson, L. and Kecklund, G. Work organisation and unintentional sleep: results from the WOLF study. Occup. Environ. Med., 2002, 59: 595-600.

Akila, D.R. (2012). A Study On Employee Retention Among Executives At Bgr Energy Systems Ltd, Chennai. International Journal of Marketing, Financial Services \& Management Research, 1(9), 18-32.

Akinci, Z. (2002): “Turizm Sektöründe Ýpgören Ýp Tatminini Etkileyen Faktörler: Bep Yýldýzlý Konaklama Ý pletmelerinde Bir Uygulama”, Akdeniz Üniversitesi Ýktisadi ve Ýdari Bilimler Fakültesi Dergisi, 4: 1-25.

Alkandari Q., (2009), employee's retention in private sector an exploratory study in the State of Kuwait.

Amador, J. and Cabral, S. (2008a), Vertical specialization across the world: A relative measure, Working Paper 10-2008, Banco de Portugal.

Ara, I. (2014). Is Pakistan's Manufacturing Sector Competitive. The Pakistan Development Review 43(4), 685-706.

Arnold, E. (2005). Managing human resources to improve employee retention. The Health Care Manager, 24(2), 132-140.

Bernsen, P. et al. (2009). Learning under pressure: Learning strategies, workplace climate, and leadership style in the hospitality industry. International Journal of Human Resource Development and Management, 9(4), 358-373.

Bevan, S. L., P. R. J. North, W. M. F. Grey, S. O. Los, and S. E. Plummer (2009), Impact of atmospheric aerosol from biomass burning on Amazon dry-season drought, J. Geophys. Res., 114, D09204, doi:10.1029/2008JD011112.

Boorman S (2009). NHS Staff Health and Well-being - Final report. London: Department of Health. Available at www.nhshealthandwellbeing.org (accessed on 22 February 2012).

Clements, P.T. et al. (2003). Cultural considerations of loss, grief, \& bereavement. Journal of Psychosocial Nursing and Mental Health Services, 41(7), 18-26.

Coats D, Max C. 2005.Healthy work: productive workplaces. Why the UK needs more "good jobs". The Work Foundation, London (accessed 19 January 2006).

Coff, R.W.1997. Human Assets and Management Dilemmas: Coping with Hazards on 
the Road to Resource-Based Theory . Academy of Management Review, 22, 2: 374402.

Davies, V., Sirett, L., \& Taylor, J. (2001). One Year On: Client' Medium-Term Experiences of One. The Charlesworth Group.

Hansia , B, (2009) . factors influencing job satisfaction,

Hiltrop, J.M (1999). The Quest for the Best: Human Resource Practices to Attract and Retain Talent. European Management Journal. 17(4), 422-430.

Hussain, Y. et al. (2011). Job Satisfaction in Private Banking Sector of Pakistan. Global Journal of Management and Business Research, 11(12), 84-94.

Iaffaldano, M. T., \& Muchinsky, P. M. (1985), Job satisfaction and job performance: A Meta analysis, Psychological bulletin, 97(2), 251.

Ivancevich, J. M. et al. (1990) Worksite stress management interventions, American Psychologist 45(2): 252-261.

Jain, D.R and Kaur, S. (2014). Impact Of Work Environment On Job Satisfaction. International Journal of Scientific and Research Publications, 4(1), 1-8.

Johnson, M. (2000), Winning the People War, Talent and the Battle for Human Capital, Copyright Licensing Agency, London.

Kilic, D.G. (2009), The Effects Of Occupational Health And Safety Risk Factors On Job Satisfaction In Hotel Enterprises. Ege Academic Review, 9(3), 903-921.

Klein, K.J. et al., (1994), "Levels issues in theory development, data collection, and analysis". Academy of Management Review, 19, 195-229.

Lowe et al. (2003). "Correlates of Employees' Perceptions of a Healthy Work Environment," American Journal of Health Promotion 17(6).

Luddy N (2005). Job satisfaction amongst employees at a public health institution in the Western Cape. Unpublished Master of Commerce degree thesis. Universityof the Western Cape.

Makie V. (2006). Stress and coping strategies amongst registered nurses working in a South African tertiary hospital. Unpublished Master of Commerce degree thesis. University of the Western Cape.

Mariani D, Gcaba R, Dalton J (2003). Survey on knowledge, attitude and practice (KAP) on professional nurses working at primary health care level. Retrieved from http://www.kznhealth.gov.za/italian/kapsyrvey.pdf. February 20, 2005. 
Maslow AH (1943), a theory of human motivation, Psychol. Rev. 50 (4), 370-396.

Miller, C. T. et al., (2001). Implications of mental models of self and others for the targets of stigmatization. In M. R. Leary (Ed.), Interpersonal rejection (pp. 189-212). New York: Oxford University Press.

Miner, J.B., Ebrahimi, B., \& Wachtel, J.M. (1995). How deficiency in management contributes to the United States' competiveness problem and what can be done about it? Human Resource Management. Fall, p. 363.

Nawaz, et al. (2012). Determinants of Employee Retention in Pakistan International Airlines (PIA). European Journal of Business and Management, 4(7), 45-53.

Ongori, H. (2008). A review of the Literature on Employee Turnover. African Journal of Business Management, 1(3), 1-54.

Paul, (2001). Job satisfaction, India, Sage

Samuel, M.O. and Chipunza, C. (2009). Employee retention and turnover: Using motivational variables as a panacea. African Journal of Business Management, 3(8), 410-415.

Shamsuzzoha, and Shumon,(2010)," Employee Turnover-a Study of its Causes and Effects to Different Industries in Bangladesh " International Journal of Humanities and Social Science [Special Issue - July 2012].

Shief , M , (2001). Motivation and Job Satisfaction , Boise State University

Smit JA (2006). The influence of coping and stressors on burnout and compassion fatigue among health care professionals. Unpublished Ph.D degree thesis. Universityof Free State.

Spector, Paul E. (1985). Measurement of Human Service Staff Satisfaction: Development of the Job Satisfaction Survey. American Journal of Community Psychology, Vol. 13, No. 6.

Spurgeon, A. (2003). Working time: Its impact on safety and health, International Labour Office, Occupational Safety and Health Research Institute, Korea Occupational Safety and Health Agency.

Sutherland, M.M. (2004). Factors affecting the retention of Knowledge Workers. PhD Dissertation, Faculty of Economics and Management Sciences, University of Johannesburg.

Tobi, S. M. N. et al. (2013). Job Satisfaction and Social Health (HRQOL) among 
Administrative Employees in Malaysian Government Sector. PDER, 64(16), 14-78.

Wilson, K., Brown, M., \& Cregan, C. (2008). Job quality and flexible practices: An investigation of employee perceptions. The International Journal of Human Resource Management, 19:3, 473-486.

Winterton, J. (2011). A conceptual model of Labor Turnover and Retention. Human Resource Development International, 7(3).

Zuber A (2001). "A career in food service cons: high turnover", Nations Restaurant News, 35 (21):147-148.

Light, Joel N., (2004). Relationships and effects of employee involvement, employee empowerment and employee satisfaction by job-type in a large manufacturing environment, Unpublished PhD. Dissertation.

McShane, S.L. \& Von Glinow, M.A. (2005), Organizational Behavior (3th ed.). India: Tata McGraw-Hill Inc.

Wetprasit, P. (2006), Impact of work-related determinants on job satisfaction and retention intentions in Thai spa industry, Unpublished PhD. Dissertation. 


\section{APPENDIX}

Figure 1

Conceptual Framework

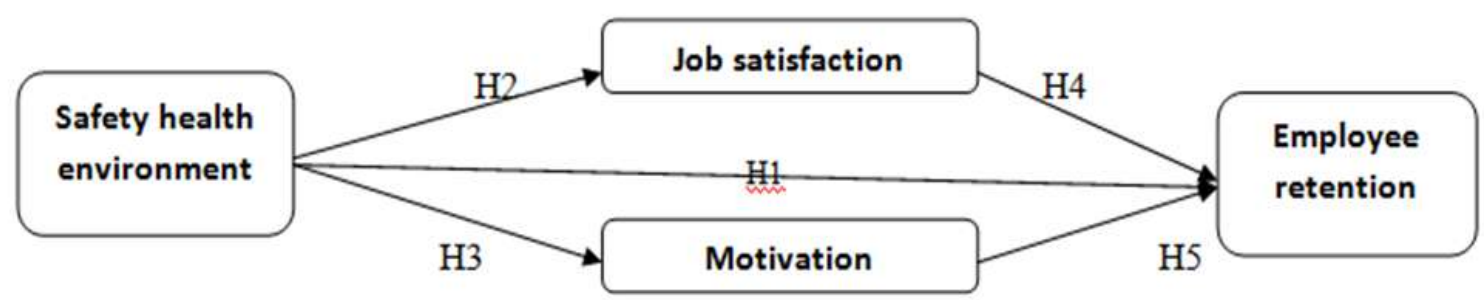

\section{Figure 2}

The research model showing regression weights obtained through Structural Equation Modeling (SEM)

\section{Table 1}

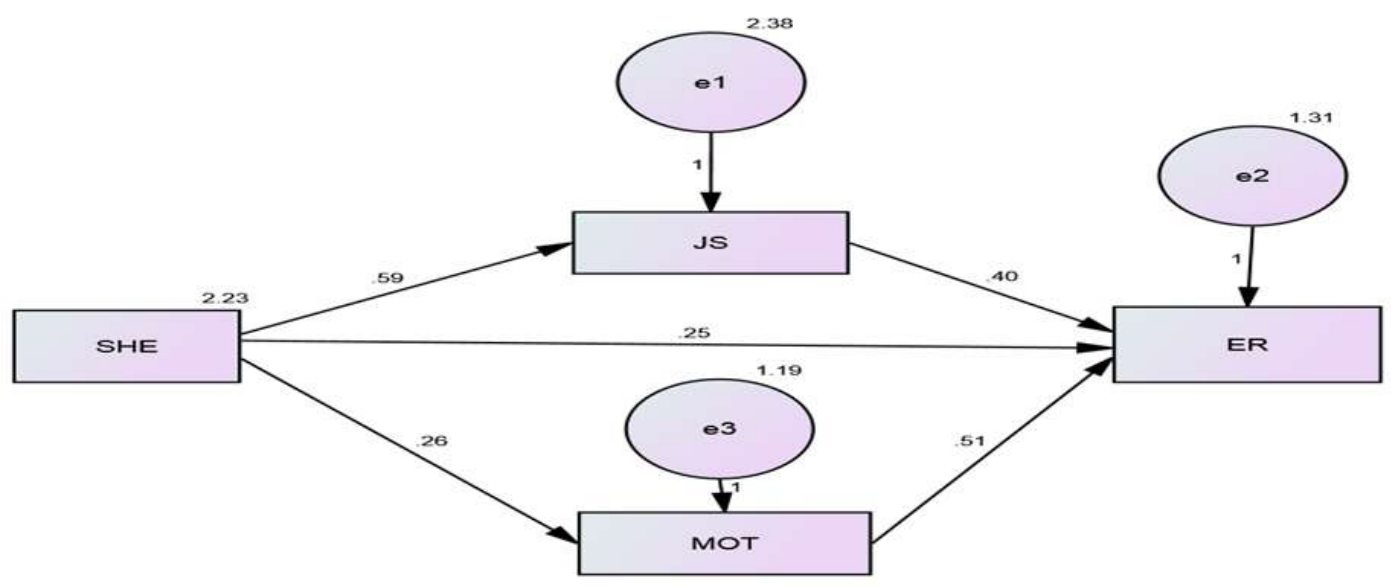


Regression analysis of variables includedRegression analysis of variables included

\begin{tabular}{|l|l|l|l|l|}
\hline Association in the model & Hypotheses & Estimate & P & Remarks \\
\hline $\begin{array}{l}\text { safety health environment } \rightarrow \text { employee } \\
\text { retention }\end{array}$ & $\mathrm{H} 1$ & .246 & $* * *$ & Accepted \\
\hline safety health environment $\rightarrow$ job satisfaction & $\mathrm{H} 2$ & .592 & $* * *$ & Accepted \\
\hline safety health environment $\rightarrow$ motivation & $\mathrm{H} 3$ & .261 & $* * *$ & Accepted \\
\hline job satisfaction $\rightarrow$ employee retention & $\mathrm{H} 4$ & .397 & $* * *$ & Accepted \\
\hline motivation $\rightarrow$ employee retention & $\mathrm{H} 5$ & .512 & $* * *$ & Accepted \\
\hline
\end{tabular}

